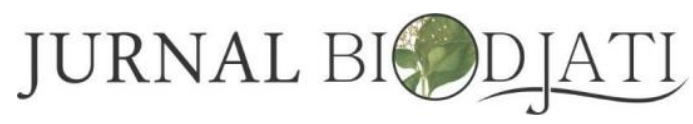

http://journal.uinsgd.ac.id/index.php/biodjati

\title{
KEARIFAN EKOLOGI ORANG BADUY DALAM KONSERVASI PADI DENGAN "SISTEM LEUIT"
}

\author{
Johan Iskandar' ${ }^{1}$, Budiawati Supangkat Iskandar ${ }^{2}$ \\ ${ }^{1}$ Prodi Biologi dan Sekolah Pascasarjana Ilmu Lingkungan, PPSDAL-Unpad. \\ ${ }^{2}$ Prodi Antropologi, FISIP Unpad
}

Diterima 22 April 2017

Disetujui 26 Mei 2017

Publish 31 Mei 2017

Korespondensi :

Jl. Raya Bandung-Sumedang

Km 21, Jatinangor Sumedang 45363, Jawa Barat.

Tel.22-797712

J1. Raya Bandung-Sumedang

$\mathrm{Km}$ 21, Jatinangor Sumedang 45363, Jawa Barat.

Tel. 778418 \& 7796416

email:

'johan.iskandar@unpad.ac.id,

${ }^{2}$ budiawati.supangkat@unpad.a c.id

e-ISSN : $2541-4208$

p-ISSN : 2548-1606
Abstrak. Ditilik dari sejarah ekologi, di masa silam sebelum ada program modernisasi usaha tani sawah melalui program Revolusi Hijau, para petani sawah di Jawa Barat dan Banten guyub menyimpan padi hasil panen padi di lumbung (leuit). Kini sistem lumbung padi tersebut hampir punah di Jawa Barat dan Banten. Namun masyarakat Baduy yang bermukim di Desa Kanekes, Kecamatan Leuwidamar, Kabupaten Lebak, Banten Selatan, kebiasaan menyimpan padi pada sistem leuit masih kokoh dipertahankan secara lekat budaya dan berkelanjutan. Paper ini mendiskusikan tentang kearifan ekologi Orang Baduy dalam mengkonservasi padi dengan sistem leuit. Metoda penelitian menggunakan kualitatif dengan pendekatan etnoekologi. Hasil penelitian menunjukkan bahwa Orang Baduy memiliki kearifan ekologi, seperti mampu menyimpan padi ladang hasil panen mereka pada lumbung padi (leuit) secara tahan lama dalam kurun waktu hingga puluhan tahun. Padi ladang utamanya hanya digunakan untuk memenuhi berbagai upacara adat dalam kegiatan berladang dan untuk dikonsumsi sehari-hari, terutama apabila Orang Baduy tidak memiliki cukup uang untuk membeli beras sawah dari warung. Maka seyogianya kearifan ekologi Orang Baduy ini dapat dipadukan dengan pengetahuan ilmiah Barat, guna dimanfaatkan dalam progam pembangunan keamanan dan ketahanan pangan secara berkelanjutan berbasis pemberdayan masyarat di Indonesia.

Kata kunci: kearifan ekologi, sistem leuit, katahanan pangan, Orang Baduy

\begin{abstract}
Based on ecological history, in the past before introducing the commercialization of the wet-rice cultivation through the Green Revolution program, the farmers of wet-rice cultivation systems of West Java and Banten predominantly stored the harvested rice in the rice barn (leuit). Nowadays, the rice-barn systems, however, have nearly disappeared in West Java and Banten. Although it has almost extinct in West Java and Banten, the Baduy community who reside in the village of Kanekes, sub-district of Leuwidamar, district of Lebak, South Banten, has strongly maintained the tradition of storing the swidden rice in the rice barns that is strongly embedded by culture and sustainable system. This paper discusses ecological wisdom of Baduy people in the conservation of the rice through the rice barn system. Method used in this study was qualitative with ethnoecological approach was applied. The result of
\end{abstract}




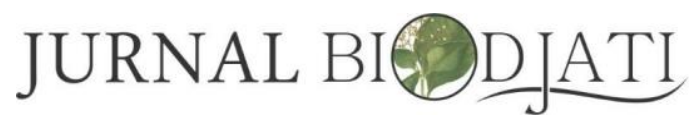

http://journal.uinsgd.ac.id/index.php/biodjati

study shows that the Baduy people have ecological wisdoms, such as able to maintain the harvested dry rice grain in the rice barn with durable condition for a long time about several decades. The swidden rice has mainly used to fulfill the traditional rituals of the swidden farming activities and for daily home consumption, particularly if the Baduy household has not enough money to buy the sawah rice from small shops. This ecological wisdom of the Baduy community, therefore, it may be usefully hybridized with Scientific Western Knowledge to benefit to use for sustainable food security and food resilience program based on the initiative community empowerment program in Indonesia.

Key words: ecological wisdom, rice barn system, Baduy people

\section{Cara Sitasi}

Iskandar, J., \& Iskandar, B. .S. (2017). Kearifan Ekologi Orang Baduy dalam Konservasi Padi dengan "Sistem Leuit". Jurnal Biodjati, 2 (1), 38-51.

\section{PENDAHULUAN}

Berdasarkan sejarah ekologi atau sejarah lingkungan, pada masa silam sebelum era 1970-an, penduduk pedesaan di Jawa Barat dan Banten bercocok tanam padi dilandasi kuat oleh pengetahuan ekologi lokal (local ecological knowledge atau local knowldge) dan kepercayaan (belief atau cosmos) (Iskandar dan Iskandar 2011; Adimihardja 2004). Pengaruh positifnya, para petani dalam mengelola lahan pertaniannya sangat hati-hati, sehingga kerusakan lingkungan, seperti pencemaran lingkungan oleh pestisida tidak terjadi dan keseimbangan ekosistem sawah ataupun ladang juga dapat terpelihara. Selain itu, secara tradisi padi-padi gabah hasil panennya guyub disimpan di lumbunglumbung padi (leuit). Namun, dewasa ini sistem pertanian sawah di berbagai perdesaan Jawa Barat dan Banten lebih dilandasi kuat oleh kepentingan ekonomi pasar. Konsekuensinya, kini para petani sawah sangat tergantung pada berbagai asupan dari luar, seperti pestisida pabrikan. Akibatnya, terjadi pencemaran lingkungan oleh pestisida secara masif dan sering terjadi ledakan hama, seperti hama wereng coklat (Nilaparvata lugens Stal), karena keseimbangan ekosistem sawah terganggu, seperti musuh-musuh alami hama tersebut banyak yang punah keracunan pestisida (Fox 2016; Winarto 2016). Selain itu, kebiasaan penyimpanan padi di lumbunglumbung padi guna mendukung ketahanan pangan penduduk perdesaan oleh para petani hampir punah. Berbagai dampak negatif tesebut, antara lain diakibatkan oleh pengaruh sampingan dari program modernisasi usaha tani sawah melalui program Revolusi Hijau di awal tahun 1970-an.

Walaupun kebiasaan penyimpanan padi di leuit di berbagai kawasan perdesaan Jawa Barat dan Banten hampir punah, namun masyarakat Baduy yang bermukim di Desa Kanekes, Kecamatan Leuwidamar, Kabupaten Lebak, Banten Selatan, masih tetap kokoh mempertahankan aturan adat (pikukuh) Baduy, menyimpan padi gabah kering hasil berladang (ngahuma) di lumbung-lumbung padi (leuit). Serta padi-padi gabah yang disimpan di leuitleuit tersebut dapat tahan hingga mencapai lebih dari 50 tahunan, dengan kondisi baik dan masih layak untuk dikonsumsi. Padahal, bagi para petani sistem sawah modern komersil Pasca Revolusi Hijau di berbagai kawasan non-Baduy tidak memiliki kemampuan lagi 


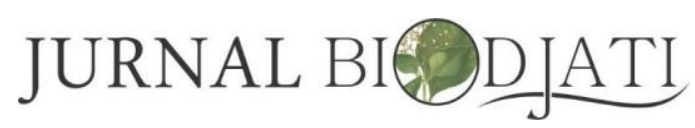

http://journal.uinsgd.ac.id/index.php/biodjati

untuk menyimpan padi jangka panjang tanpa rusak.

Pada umumnya, padi-padi gabah ladang yang disimpan di lumbung-lumbung padi (leuit) Baduy tetap terjaga dari kerusakan dan terhindar dari serangan hama, seperti tikus dan serangga. Hal tersebut dikarenakan padi di dalam leuit dikelola secara seksama oleh tiap keluarga Baduy berdasarkan pengetahuan lokal atau pengetahuan ekologi lokal secara lekat budaya, yang diwariskan secara turun temurun dari leluhurnya secara lisan menggunakan bahasa ibu, bahasa Sunda (bandingkan Toledo 2000; Carlson dan Maffi 2004; Berkes 2008). Secara umum, pengetahuan lokal (local knowledge) atau biasa disebut pula dengan berbagai sebutan lainnya, seperti pengetahuan ekologi lokal (local ecological knowledge), pengetahuan ekologi tradisional (traditional ecological knowledge), pengetahuan penduduk perdesaan (rural people's knowledge), pengetahuan penduduk tentang lingkungan (indigenous environmental knowledge), danpengetahuan rakyat (folk konowlede), dalam konteks pembangunan dapat diartikan sebagai pengetahuan bersifat kolektif yang dimiliki oleh suatu populasi, yang dikomunikasikan secara lisandengan menggunakan bahasa ibu, bersifat holistik, sangat mendalam tapi sangat spesifik lokal, berhubungan dengan berbagai ranah, terutama dalam pengelolaan sumberdaya alam, dan sangat rentan terhadap kepunahan (Ellen dan Harris, 2000 ; Sillitoe, 2002).

Berbagai studi tentang masyarakat Baduy dan sistem pengelolaan sistem ladang masyarakat Baduy telah banyak dikaji oleh para peneliti. Demikian pula, beberapa aspek tentang sistem leuit Baduy, telah ada yang mengkajinya, seperti tentang sistem arsitektur leuit (Jamaludin, et al., 2013), etnomatematik leuit (Aristeyawan, et al., 2014), dan tatabangunan leuit (Al-ansori, et al., 2015). Namun, studi khusus tentang sistem leuit Baduy kaitannya dengan konservasi padi lokal, belum ada yang mengkajinya. Padahal, aspek ini sungguh menarik dikaji karena masyarakat Baduy mampu mempertahanan keamanan dan ketahanan pangan, antara lain disebabkan setiap keluarga Baduy memiliki leuit.

Paper ini mendiskusikan tentang kearifan ekologi masyarakat Baduy dalam mengkonservasi padi ladang dengan sistem leuit secara berkelanjutan, dengan dilandasi kuat oleh pengetahuan ekologi lokal dengan secara lekat budaya.

\section{BAHAN DAN METODE}

Penelitian ini dilakukan di lapangan yaitu di kawasan Baduy, di Desa Kanekes, Kecamatan Leuwidamar, Kabupaten Lebak, Provinsi Banten (Gambar 1). Khususnya, studi kasus dilakukan di Kampung Kaduketug Baduy Luar dan Kampung Cibeo, Baduy Dalam. Secara geografi lokasi Desa Kanekes ini terletak pada $6^{0} 27^{\prime} 27^{\prime}$ '-6 30 ' Lintang Selatan dan 108 3 '9"' Bujur Timur. Total wilayahnya secara keseluruhan sekitar 5.136,58 ha. Berdasarkan adat, kawasan Baduy ini dapat dibagi menjadi 2 wilayah utama yaitu kawasan Baduy Dalam (Baduy Jero) dan Baduy Luar (Baduy Luar atau Panamping). Baduy Dalam terdiri dari 3 kampung yaitu Kampung Cibeo, Kampung Cikartawarna dan Kampung Cikeusik. Sementara itu, Baduy Luar terdiri dari lebih 50 kampung (Wessing dan Barendregh, 2005 ; Iskandar dan Iskandar, 2017). 


\section{JURNAL BIDDJATI}

http://journal.uinsgd.ac.id/index.php/biodjati

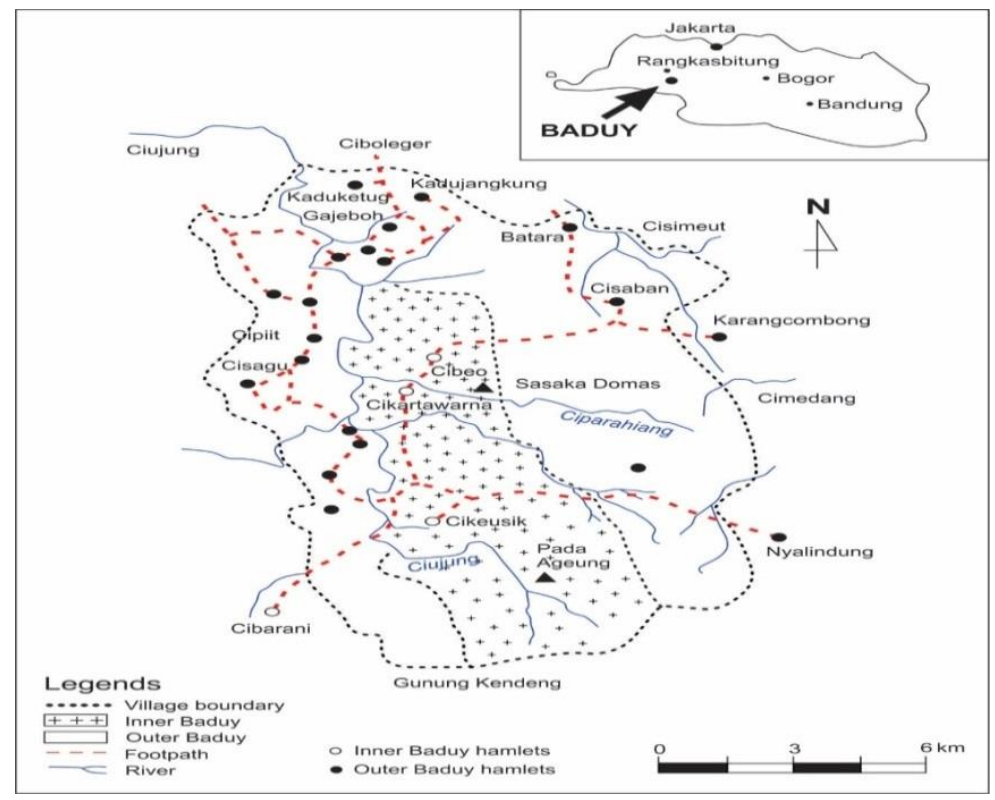

Gambar 1. Peta lokasi penelitian di kawasan Baduy, Desa Kanekes, Kecamatan Leuwi Damar, Kabupaten Lebak, Banten Selatan

Jumlah penduduk Baduy pada tahun 2015, tercatat total 11.620 orang, terdiri dari 3.395 kepala keluarga (KK) (Statistik Desa Kanekes, 2015). Jumlah penduduk tersebut sekitar 90\% merupakan penduduk Baduy Luar dan sisanya $10 \%$ penduduk Baduy Dalam.

Pekerjaan utama masyarakat Baduy adalah berladang atau ngahuma (Ichwandi dan Shinohara, 2007 ; Jamaludin, 2012; Suparmini et al., 2013; Iskandar dan Iskandar 2017). Berladang bagi masyarakat Baduy dianggap sebagai kewajiban dalam agama mereka, yang disebut Sunda Wiwitan. Berdasarkan adat Baduy, menggarap ladang menerapkan berbagai pantangan atau tabu, seperti pantang menggunakan benih padi modern, pupuk sintesis an-organik dan pestisida pabrikan, serta memperdagangkan padi hasil ladang. Mereka juga pantang menggarap sawah; memelihara ternak kerbau, sapi, dan domba; bertanam jenis tanaman komersil secara monokultur monokultur, seperti cengkeh, coklat, karet, jati, dan lain-lain monokultur, seperti cengkeh, coklat, karet, jati, dan lainlain.

Metoda yang digunakan dalam studi ini bersifat kualitatif dengan pendekatan etnoekologi (Martin, 1995 ; Newing et al., 2011 ; Albuquerque et al., 2014).Teknik dalam pengumpulan data lapangan yaitu melakukan observasi lapangan, wawancara semi-struktur, dan observasi partisipasi. Observasi lapangan utamanya melakukan pengamatan terhadap kondisi permukiman (kampung), ladang (huma), lumbung padi (leuit), hutan tua (leuweung kolot), hutan sekunder (reuma). Wawancara semi-struktur dilakukan terhadap informan yang dipilih secara purposive yang dianggap kompeten dengan memperhatikan keragamannya, seperti kepala desa (jaro pemerintah), sekretaris desa (carik), tetua kampung (kolot lembur), staf puun bagian adat (jaro tangtu) Cibeo, serta beberapa petani tua laki dan perempuan di Cibeo, Baduy Dalam dan Kampung Kaduketug, Baduy Luar. Sementara itu, observasi partisipasi dilakukan 


\section{JURNAL BIODJATI}

http://journal.uinsgd.ac.id/index.php/biodjati

dengan cara peneliti ikut terlibat dalam beberapa kegiatan berladang Orang Baduy, seperti panen padi, memasukan padi ke lumbung padi (leuit) dan merawat padi di leuit.

Data lapangan yang terkumpul dari hasil observasi, observasi partisipasi, dan wawancara semi-struktur dianalisis dengan cara pengecekan data secara silang (crosscheking), perangkuman (summarizing) dan pensintesaan (synthesizing), serta dinarasikan secara deskriptif analisis secara runut (Newing et al., 2011).

\section{HASIL}

Berdasarkan hasil studi lapangan menunjukkan bahwa hasil padi ladang (pare huma) masyarakat Baduy pantang diperdagang kan. Padi huma utamanya digunakan untuk memenuhi kebutuhan berbagai upacara adat dalam kegiatan berladang pada setiap tahunnya, seperti tanam padi (ngaseuk), panen padi (mipit pare atau dibuat), dan upacara persembahan padi baru pada leluhur di Baduy Dalam (upacara kawalu) dan di Baduy Luar (upacara ngalaksa), serta untuk konsumsi sehari-hari dalam keluarga.

Padi huma dikonsumsi sehari-hari oleh keluarga Baduy, terutama apabila keluarga tersebut tidak cukup uang untuk membeli beras sawah dari warung. Sementara uangnya, diperoleh dari hasil menjual anekaragam produksi tanaman non-padi, seperti petai (Parkia speciosa Hassk), durian (Durio zibethinus Murr), pisang (Musa paradisiaca $\mathrm{L}$ ) dan lainnya. Mengingat memperdagangkan anekaragam hasil pertanian non-padi tidak tabu bagi masyarakat Baduy. Oleh karena itu, anekaragam non-padi marak diperdagangkan, namun padi hasil dari ladang tabu dijual dan utamanya disimpan oleh tiap keluarga di lumbung-lumbung padi.

\section{Lumbung Padi (Leuit)}

Lumbung padi (leuit) Baduy adalah merupakan bangunan khusus dipergunakan untuk menyimpan padi ladang oleh tiap keluarga masyarakat Baduy. Lumbunglumbung padi umumnya ditempatkan di sekeliling pemukiman di kawasan hutan kampung (dukuh lembur). Lokasi yang dipilih untuk tempat leuit di bawah pepohonan rimbun dukuh lembur, tapi masih cukup dapat penyinaran matahari dan juga terlindung dari air hujan, ketika hujan turun di musim penghujan.

Pada masyarakat Baduy dikenal ada 3 tipe lumbung padi (leuit) yaitu leuit lenggang, leuit mandiri, dan leuit karumbung (Gambar 2). Leuit lenggang memiliki karakteristik, antara lain memiliki 4 tiang penyangga dengan tingginya sekitar $1 \mathrm{~m}$. Pada tiap dasar tiang tersebut tidak langsung menyentuh tanah karena diberi alas batu yang permukaannya agak rata (tatapak), dimaksudkan agar tiang leuit tidak basah dan terhindar dari serangan rayap (rinyuh). Di bagian atas tiang-tiang tersebut disambungkan dengan bangunan leuit seperti rumah panggung, yang berbentuk persegi empat dengan bagian atas ukurannya lebih besar, dengan tinggi sekitar $2,5 \mathrm{~m}$, sehingga kalau dipasang dengan bagian atapnya membentuk trapesium. Di antara tiap tiang penyangga dan bangunan utama leuit terdapat penyangga berupa papan bulat berupa padati yang disebut gelebeg, dengan diameter sekitar $30 \mathrm{~cm}$. Pada bagian utama dinding leuit disusun oleh kerangka kayu untuk memasang dinding bambu (bilik). Kemudian, pada bagian atap bangunan leuit dibangun kerangkakerangga dari bambu dan kayu, yang disebut layeus, untuk memasang atap leuit. Atap leuit (hateup) dibuat dari daun kiray yang disusun atau dirangkai dengan tusukan bambu seperti tusukan sate (jajalon) tapi ukurannya panjang. Tiap jajalon daun kiray memiliki ukuran 


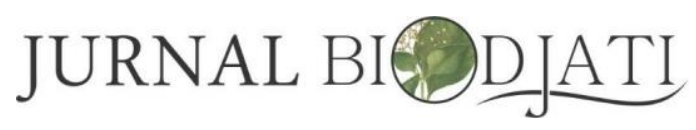

http://journal.uinsgd.ac.id/index.php/biodjati

sekitar $1 \mathrm{~m}$ x $1 \mathrm{~m}$. Pada bagian atas atap berupa jajalon-jajalon daun kiray ini biasa dilapisi oleh ijuk aren, agar atap leuit lebih tahan lama. Di antara badan leuit dengan atap leuit terdapat pintu untuk memasukan atau mengeluarkan padi dari dalam leuit. Mengingat pintu leuit cukup tinggi, maka untuk memasukan dan mengeluarkan padi dari leuit biasanya penduduk menggunakan tangga dari bambu (taraje).

Tipe leuit mandiri bentuknya hampir sama dengan leuit lenggang, tapi pada tiangtiangnya tidak memiliki gelebeg. Sementara itu, leuit karumbung memiliki ciri khas, antara lain bentuknya persegi empat, dengan 8 tiang penyangga atau kaki leuitagak pendek sekitar $3 \mathrm{~cm}$, dengan bangunan leuitnya panjangnya sekitar 2-3 m, dengan lebar $2 \mathrm{~m}$.

Anekaragam bahan yang digunakan untuk membuat leuit,antara lain batu, kayu, bambu, daun kiray dan ijuk aren diperoleh dari lingkungan setempat. Misalnya, batu untuk alas kaki tiang leuit biasa diambil dari sungai, seperti S. Ciujung. Anekaragam kayu untuk bahan leuit dipilih jenis-jenis kayu keras ataupun bagian dalam kayu (galih) yang keras, seperti cangcaratan (Neonauclea excelsa (Blume) Merr), bareubeuy (Helica serrata), leungsir (Pometia pinnata), dan huru (Litsea sp.), yang diperoleh dari hutan tua (leuweung kolot). Jenis kayu lainnya, seperti kayu laban (Vitex trifolia L), kihiang(Albizia procera (Roxb) Bnth), dan nangka (Artocarpus heterophyllus L) biasanya dipanen dari hutan sekunder (reuma). Selain itu, daun kiray (Metroxylon sagu Rottb), ijuk aren (Arenga pinnata (Wurmb) Merr), bambu apus (Gigantochloa apus (Bl. ex Schultf) Kurz) dan bambu mayan (Gigantochloa robusta Kurz) biasa dipungut dari reuma ataupun dukuh lembur.

Membuat leuit cukup rumit dan diperlukan pengetahuan dan keahlian khusus.
Tata-cara membuat leuit, seperti leuit lenggang, yaitu pertama, mengumpulkan balok-balok kayu untuk bahan tiang, galang dan sundukleuit. Kayu-kayu tersebut agar kuat dan tahan terhadap serangan serangga hama perusak kayu, seperti bangbara, toko, dan kaleker,biasanya sebelum digunakan, direndam dulu dalam air dan lumpur. Kedua, berbagai glondongan kayu tersebut dibentuk untuk tiang-tiang leuit, dengan dibuat lubanglubang seukuran sunduk, guna memasang sunduk agar keempat tiang leuit menyatu dengan sunduk tanpa menggunakan paku. Ketiga, memasang 4 batu sebagai dasar (tatapakan) guna menapakan tiang leuit ke tanah. Pada tiang yang berdiri di atas tatapakan tersebut pada bagian atasnya diletakan 4 kayu galang yang ditumpangkan satu sama lainnya. Keempat, memasang kakikaki tiang leuit yang disebut parako handap, serta gelebeg dipasang pada kaki leuit tersebut. Kelima, usai gelebeg dimasukan, selanjutnya dipasang tiang-tiang leuit di atasnya dengan membentuk bagian atasnya lebih luas (lenggang), dengan lebar sekitar 3,5 m, dan lebar bagian bawahnya sekitar 2,5 m. Keenam, tiap tiang leuit dimasukan ke dalam lubang sunduk yang lubangnya telah disediakan, sehingga membangun kerangka bangunan utama leuit. Pada bagian bawah atau lantai leuit dipasang bambu mayan yang telah dicercah-cercah (palupuh). Selain itu, dinding leuit berupa dinding bambu (bilik) dipasang di seluruh bagian dinding leuit. Agar bilik terpasang dan menempel kuat di dinding, lembaran-lembaran bambu tersebut di bagian dalamnya ditahan oleh bilah-bilah bambu apus (dempet). Selain itu, bagian luarnya juga dipasang penahan, sehingga dinding bambu benar-benar menempel kuat di dinding leuit. Ketujuh, pembuatan atap (hateup) leuit, yaitu dilakukan pemasangan kerangka-kerangka atap leuit (layeus) dari kayu dan bambu untuk 


\section{JURNAL BIDDJATI}

http://journal.uinsgd.ac.id/index.php/biodjati

memasang atap dari daun kiray dan ijuk aren. Usai pemasangan kerangka-kerangka atas, selanjutnya lembaran-lembaran daun kiray yang telah disusun (jajalon) dipasang untuk menutupi atap leuit, serta bagian atasnya dilapisi oleh ijuk aren. Tidak ketinggalan, dibuat pula pintu leuit guna menutup dan membuka leuit, letaknya di bagian atas.

Pembuatan leuit Baduy biasanya membutuhkan dana cukup besar, terutama untuk pembuatan leuit di Baduy Luar. Pasalnya, berbagai bahan untuk membuat leuit sulit diperoleh di kawasan Baduy Luar. Misalnya, untuk mendapatkan kayu-kayu keras bahan leuit perlu membelinya dari tempat lain. Pasalnya, di kawasan Baduy Luar tidak memiliki hutan tua (leuweung kolot) yang luas, tempat tumbuh kayu-kayu keras tersebut. Sebagai gambaran umum untuk membuat leuit karumbung ukuran 2,5 m x 2,5 $\mathrm{m}$, pada tahun 2015 dibutuhkan biaya lebih dari 5 juta rupiah. Biaya tersebut diperlukan misalnya untuk membeli batang-batang kayu, untuk potongan kayu sageleng dengan panjang $3 \mathrm{~m}$, dibutuhkan tak kurang dari 16 geleng dengan harga per gelengnya $\mathrm{Rp}$ 60.000,-Keperluan atap leuit (hateup leuit) berupa lembaran-lembaran daun kiray (jalon), dibutuhkan sekurangnya 60 jalon ukuran besar dengan harga $\mathrm{Rp}$ 5.000/jalon. Kayu-kayu untuk kerangka atap (layeus) dari bahan awi apus, butuh 30 layeus atau sekitar 5 pohon awi apus, dengan harga satu pohon awi apus sekitar Rp 5.000. Pada satu batang bambu tersebut, biasanya bagian pangkalnya digunakan untuk bilik dan bagian ujungnya untuk dibuat layeus. Sementara itu, upah buruhnya $\mathrm{Rp} 80.000 /$ hari, dengan total pengerjaan perlu waktu sekitar 50 hari kerja. Biaya untuk pembuatan leuit lenggang dan leuit mandiri perlu biaya yang lebih mahal lagi karena bahan-bahan yang dibutuhkannya lebih banyak. Oleh karena itu, tidaklah heran bahwakini tipe leuit yang dominan di kawasan Baduy Luar adalah dari tipe leuit karumbung, sedangkan di Baduy Dalam masih banyak penduduk yang memiliki leuit lenggang.Untuk leuit lenggang atau leuit mandiri biasanya dapat diisi padi gabah sekitar 500-1000 ikat (pocong), sedangkan untuk leuit karumbung bisa diisi sekitar 400-500 pocong padi gabah. Kekuatan leuit tersebut dapat tahan mencapai 25 tahun, tapi bagian atapnya yang tanpa ijuk biasanya diganti tiap 2-3 tahun sekali atau apabila pakai ijuk dapat tahan lebih lama lagi.

Pada umumnya setiap kelurga Baduy, baik Baduy Dalam maupun Baduy Luar memiliki minimal satu leuit atau bagi keluarga yang telah lama berladang biasa memiliki 2-3 leuit. Pasalnya, setiap panen ladang, sebagian besar produksi padi gabah keringnya senantiasa disimpan di leuit.

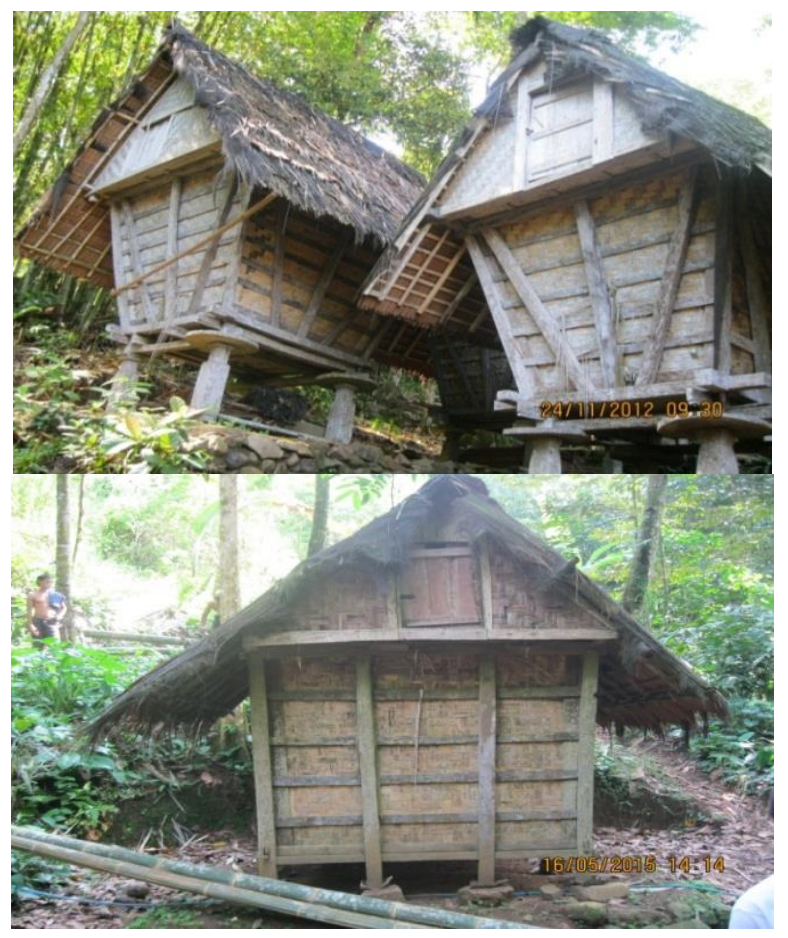

Gambar 2. Leuit Baduy tipe 'leuit lenggang' pada tiangnya memiliki pedati (gelebeg) dan 'leuit karumbung' dengan berbentuk segi empat dan tiangnya pendek 


\section{JURNAL BIODJATI}

http://journal.uinsgd.ac.id/index.php/biodjati

\section{Penyimpanan Padi di Leuit}

Gabah-gabah padi yang disimpan di lumbung padi utamanya berupa ikatan-ikatan padi yang telah dikeringkan sebelumnya dengan dijemur terik matahari di batangbatang bambu (lantayan) di pingiran dangau ladang (saung huma) atau pinggiran kampung (Gambar 3). Cara penyimpanan poconganpocongan padi gabah di dalam leuit tidak dilakukan secara sembarangan, tetapi harus mengikuti tradisi para orang tua terdahulu, dan diwariskan secara turun-temurun.

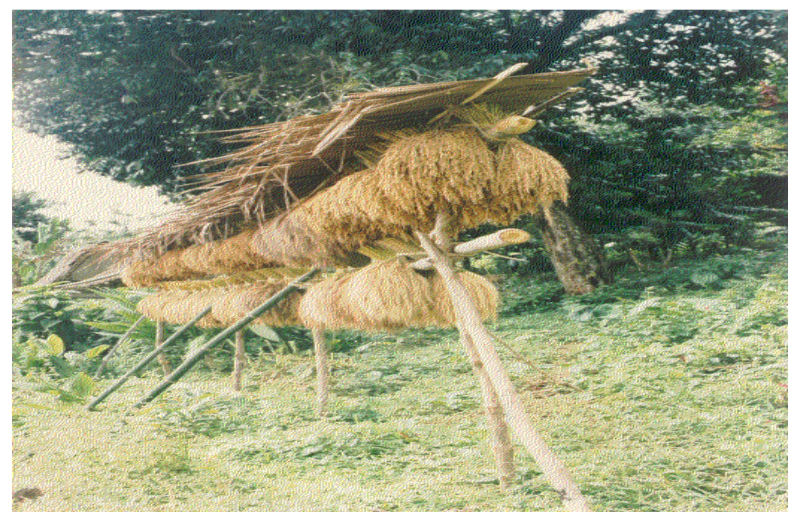

Gambar 3. Padi hasil panen dari ladang sebelum dimasukan ke dalam leuit dikeringkan dengan dijemur terik matahari pada batang bambu (lantayan)

Tata cara penyimpanan padi gabah yang lazim dilakukan oleh masyarakat Baduy sebagai berikut, -Leuit baru sebelum diisi ikatan-ikatan padi gabah, bagian lantainya ditutupi oleh daun-daun teureup (Ficus elastica Roxb) dan daun patat (Phrynium pubinerve $\mathrm{Bl}$ ), sehingga penuh tertutup daun tanpa ada celah-celah lantai yang tidak tertutupi daun. Hal tersebut sangat penting antara lain guna menjaga temperatur ruangan leuit menjadi hangat, mengingat tidak ada celah-celah udara masuk dari luar melalalui lantai leuit. Kemudian, usai lantai leuit dilapisi daun teureup dan daun patat, pocongan-pocongan padi gabah kering dimasukan, dengan tatacaranya sebagai berikut. Pertama, menyimpan padi pada lapisan pertama dengan teknik tajur pinang, pocongan-pocongan padi disimpan dengan disusun (dientep) cara diagonal, ikatan-ikatan padi gabah ditumpuk disusun mengelilingi, sehingga antar batang-batang padi bertemu di tengah. Hal tersebut dimaksudkan agar pocong-pocongan padi dapat tersimpan banyak di dalam leuit, guna menyimpan padi pada lapisan dua dan seterusnya hingga bagian atasnya. Kedua lapisan kedua dan seturusnya menggunakan teknik gilir naga, yaitu tumpukan-tumpukan padi disimpan searah jarum jam, memutar sekeliling ruang pinggir leuit hingga tengah leuit, seperti ular menggulung, hingga ke atas memenuhi leuit. Menyusun pocongan padi berlawanan dengan arah jarum jam biasanya disebut pula sebagai mapag naga. Maka, dengan penataan menyimpan padi seperti gulungan ular tersebut, menyebabkan tiap lapisan padi tidak terlalu rapat, agar ada celah untuk sirkulasi udara di dalam leuit, sehingga kelembaban udara dalam lumbung padi terjaga dengan baik dan stabil. Selain itu, untuk ikatan padi gabah khusus yang dipanen di bagian tengah ladang, tempat upacara tanam padi atau panen padi (daerah pungpuhunan) atau disebut indung pare sebanyak 2 ikat padi disimpan di bagian tengah leuit. Sementara itu, di dekat pintu leuit juga disimpan 2 ikat (pocong) padi,sebagai simbolik penjaga pintu (jaga panto) leuit. Berdasarkan tradisi masyarakat Baduy, keempat ikat padi tersebut tidak boleh ditumbuk dijadikan jadi beras dan ditanak.

Berbeda dengan pocongan padi di leuit, untuk padi bahan benih untuk ditanam di ladang pada tahun berikutnya, biasanya disimpan terpisah, seperti disimpan di dalam rumah ataupun disimpan dalam kotak kayu di kamar rumah. Padi-padi untuk bahan benih biasanya dipanen secara khusus,dengan dipilih yang berisi dan seragam dari setiap varietas 


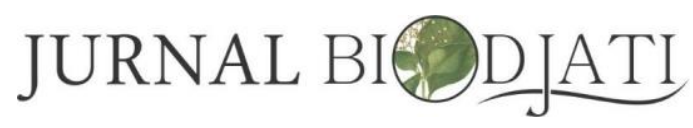

http://journal.uinsgd.ac.id/index.php/biodjati

(huasan)nya, dan disimpan secara terpisah bagi tiap varietasnya (dialean). Di antara berbagai varietas padi ladang, dikenal 3 huasan yang dianggap sakral, yaitu pare koneng, pare siang, dan pare ketan langgasari. Ketiga huasan padi tersebut merupakan wajib ditanam di ladang-ladang masyarakat Baduy, serta ditambah pula minimal 2 varietas padi lainnya untuk penyelangnya karena varietas padi sakral tidak boleh bersinggungan satu satu sama lainnya pada petak ladang. Oleh karena itu, pada setiap petak ladang umumnya ditanami keanekaan varietas padi yang tinggi, gabungan dari varietas padi sakral dan varietas non-padi sakral.

\section{Pemeliharaan Padi di Leuit}

Padi yang disimpan di leuit ada dua kategori, yaitu kategori pertama, berupa padipadi hasil panen dari kawasan tengah-tengah petak ladang, yang merupakan daerah sakral, tempat upacara waktu tanam dan panen padi,serta kategori ke dua, padi-padi hasil panen di luar daerah sakral. Padi kategori pertama atau disebut indung pare biasanya disimpan di leuit disertai dengan upacara ngadiukeun indung pare. Indung pare tersebut biasanya dibagi menjadi tiga ikat (ranggeong) yaitu satu ranggeong pare pasangan, satu raggeong pare laki dan perempuan (pare bikang jeung salaki), dan satu ranggeong pare pengantar (pare panganteur). Ranggeong pare pasangan biasanya diikat tali bambu, serta diikatkan dengan macam-macam dedaunan tumbuhan, seperti daun kukuyan (Kibara coricea (Blume) Hook.f), kakandelan (Hoya difersifolia), ilat mintul (Scleria purpurascens), tumbueusi (Phyllantusniruri L), mara asri (Macaranga triloba (Tunb.) Mull.Arg), areuy geureung (Stephania javonica (Tunb.) Miers), pacing (Costus speciosus (J. Koenig) Sm), dan teureup (Ficus elastica Roxb). Selain itu, beberapa daun tumbuhan tersebut juga biasa diselipkan di dinding leuit bagian luar. Berdasarkan kepercayaan Orang Baduy, anekaragam daun tumbuhan tersebut dianggap sebagai kegemaran Dewi Padi, Nyi Pohaci, serta berfungsi sebagai simbolik. Contohnya, daun pacing, simbolik supaya padi cicing (diam) di leuit. Daun teureup sebagai simbolik yaitu teu (tidak) dan reup (tidur), jadi padi dapat dijaga, dengan penjaga yang tak pernah tidur. Sementara itu, daun kukuyaan seabagi simbolik yaitu dikukuy (digali) ayaan (tetap ada), artinya padi gabah bila digali atau diambil dari leuit, senantiasa ada terus, tidak akan habis-habisnya.

Indung pare dibungkus boeh dan dibawa oleh perempuan ke leuit. Padi tersebut disimpan (dielep) oleh pria dibagian tengah tumpukan padi di dalam leuit. Lantas, selama tiga hari tiga malam, tiap pagi dan sore dilakukan upacara ngukus, dengan melakukan pembakaran galih gaharu (Gonystilus mcrothyllus (Miq)) sebagai kemenyan, serta pembakaran bahan lainnya, seperti cangkang pisitan (Lansium domesticum Corr), dan akar jambaka (Dianella nemorosaLam). Selain itu, dilakukan upacara ngapret, yaitu pria pemilik leuit menciprat-cipratkan air yang dicampurkan dengan ramuan tumbukan jaringao (Acorus calamus L), cikur (Kaemferia galanga L), panglay (Zingiber cassumunar Roxb) di bagian dalam dan luar leuit.

\section{Mengambil Padi di Leuit}

Hasil padi ladang dimangfaatkan utamanya untuk keperluan upacara adat dan konsumsi sehari-hari masyarakat Baduy. Untuk keperluan konsumsi, padi gabah biasanya diolah menjadi beras dengan cara ditumbuk di saung lesung (saung lisung) kampung (Gambar 4). Berdasarkan pengaturan tataruang di masyarakat Baduy, saung lesung 


\section{JURNAL BIDDJATI}

http://journal.uinsgd.ac.id/index.php/biodjati

biasanya ditempatkan di bagian utara kampung. Pengambilan padi gabah dari lumbung padi (leuit) untuk ditumbuk di lumbung padi tidak bisa dilakukan sembarangan. Berdasarkan tradisi masyarakat Baduy, hari selasa dan hari jumat, dianggap sebagai hari pantangan untuk mengambil padi gabah dari leuit. Pasalnya, pada hari-hari tersebut, Dewi Padi atu Nyi Pohaci dianggap sedang pengantinan (eukeur pangantenan).

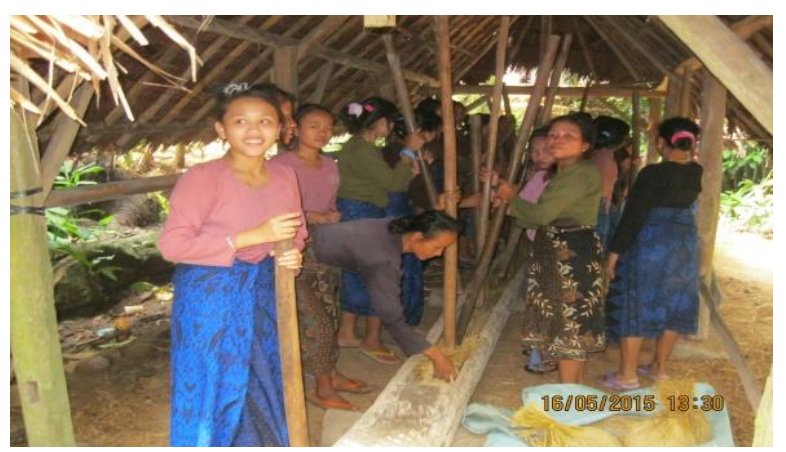

Gambar 4. Padi gabah ditumbuk di saung lesung oleh para penumbuk padi di kampung Kadukketug, Baduy Luar

Tidak hanya itu, tiap kali perempuan Baduy akan mengambil padi gabah hasil panen baru dari leuit (nguyang) untuk ditumbuk di saung lesung senantiasa diadakan upacara membangunkan padi (ngahudangkeun pare) yang disebut ngocek. Pada upacara tersebut dipersembahkan berbagai bahan untuk menyirih secara lengkap, seperti daun sirih (Piper betle L), buah pinang (Areca cathecu L), kapur dari kerang air sungai, gambir (Uncaria gambir Roxb), serta rimpang panglay (Zingiber cassumunar Roxb). Pada upacara tersebut, semua bahan-bahan untuk menyirih dan dicampur rimpang panglay dikunyah pria pemilik leuit dan disembursemburkan dari mulutnya pada padi gabah di dalam leuit dimaksudkan untuk 'membangunkan padi'. Usai upacara ngocek, beberapa ikatan padi dapat diambil dan dibawa ke saung lesung guna ditumbuk untuk dijadikan beras, dan selanjutnya berasnya biasa disimpan di suatu wadah sebangsa gentong yang disebut paso.

\section{PEMBAHASAN}

Keberadaan leuit sungguh penting bagi kehidupan masyarakat Baduy. Pasalnya, bagi masyarakat Baduy, padi-padi hasil panen ladang guyub disimpan di leuit. Padi-padi tersebut disimpan di leuit hingga tahan lama, mencapai lebih dari lima puluh tahun dengan kondisi baik dan masih tetap layak untuk dikonsumsi, sehingga menjadi cadangan pangan yang sangat penting bagi masyarakat Baduy.

Berdasarkan the International Research Institute (IRRI), padi dapat disimpan lama harus memenuhi beberapa persyaratan, seperti kadar air padi dijaga pada tingkat $14 \%$ basis basah atau lebih kecil, padi terlindung dari organisme perusak, dan padi terlindung dari kebasahan (IRRI, 2004). Maka, dengan melihat kenyataan bahwa padi-padi gabah masyarakat Baduy dapat disimpan di leuit dalam jangka waktu lama. Hal tersebut dapat mengindikasikan bahwa teknik penyimpanan gabah-babah padi di lumbung oleh masyarakat Baduy cukup sesuai dengan yang diprasaratkan oleh IRRI (2004), seperti padi gabah kadar airnya rendah, terlindung dari kebasahan, dan terlindung dari organisme perusak. Misalnya, untuk menyimpan padipadi gabah di leuit agar kadar airnya rendah, masyarakat Baduy biasanya menjemur padipadi gabah terlebih dulu hingga kering di lantayan, sebelum dimasukan ke leuit. Sementara itu, temperatur dan kelembaban di ruangan leuit juga dapat dijaga cukup stabil sepanjang tahun, baik di musim hujan maupun di musim kemarau, di antaranya karena alas leuit dilapisi oleh daun teureup dan daun patat, serta dinding bambu berupa bilik, juga 


\section{JURNAL BIDDJATI}

http://journal.uinsgd.ac.id/index.php/biodjati

cukup baik untuk mengatur aerasi dan cahaya matahari masuk ke lumbung padi. Selain itu, padi gabah di leuit juga tidak basah, terutama pada musim hujan karena atap leuit dari daun kiray dan ijuk aren cukup baik dalam menahan air hujan, tapi sekaligus juga masih memungkinkan sinar matahari masuk ke dalam leuit. Selain itu, padi di leuit juga dapat cukup terjaga dari gangguan organisme perusak, seperti serangga dan tikus. Hal tersebut antara lain karena pemilik leuit sering melakukan upara di leuit atau sekitar leuit yang dapat berfungsi mengendalikan hama. Misalnya, pada upacara tersebut biasa membakar berbagai jenis tumbuhan beraroma bau, serta meniciprat-cipratkan air dicampur dengan ramuan anekaragam tumbuhan beraroma bau di dalam leuit dan di luar leuit. Konsekuensinya, aroma bebauanan dari bahan bioaktif anekaragam tumbuhan tersebut dapat mengusir (repellants) hama padi di leuit (Reijintjes., 1992 ; Marfori et al., 2015). Disamping itu, padi ladang kuat disimpan di leuit, mengingat sistem penanaman padi ladang masyarakat Baduy, menerapkan sistem pertanian organik (organic farming system), yakni tidak menggunakan pupuk an-organik dan pestisida.

Berdasarkan konsep ketahanan pangan (Prabowo, 2010), yakni mencakup aspek ketersediaan, distribusi dan konsumsi pangan, masyarakat Baduy termasuk kategori cukup tanguh dalam ketahanan pangan dan keamanan pangan. Pasalnya, ketersediaan pangan pokok berupa beras, masyarakat Baduy memiliki kebiasaan menyimpan dan mengawetkan padi untuk jangka panjang secara berkelanjutan dalam sistem leuit.Di samping itu, ketersediaan anekaragam pangan sumber karbohidrat non-padi, seperti ubi jalar, jalar, singkong, jagung, talas, ubi manis, dan gadung juga banyak dibudidayakan secara tradisional di sistem ladang (sistem huma), dengan ditumpang sari dengan tanaman padi. Tidak hanya itu, sumber pangan non-karbohidrat, seperti bahan bumbu masak, sayur/lalap, buahbuahan, dan bahan obat-obatan juga secara tradisi ditanam secara dicampur dengan padi pada sistem agroforestri tradisional huma dan sistem agroforestri tradisional lainnya, seperti reuma dan dukuh lembur. Sementara itu, sistem distribusi pangan bagi masyarakat Baduy, secara umum pasokan pangan pokok karbohidrat berupa beras bagi tiap keluarga terdistribusi cukup merata. Pasalnya, bagi tiap keluarga Baduy, baik masyarakat Baduy Dalam dan masyarakat Baduy Luar, memiliki lahan garap ladang, serta memiliki leuit keluarga. Bagi masyarakat Baduy, kegiatan berladang dianggap sebagai kewajiban dalam agama mereka, Sunda Wiwitan. Oleh karena itu, pada setiap tahunnya setiap keluarga harus menggarap ladang, guna menghasilkan padi ladang untuk keperluan berbagai upacara adat dalam kaitannya dengan kegiatan berladang dan untuk keperluan konsumsi keluarga. Ditilik dari aspek konsumsi pangan keluarga, walupun penduduk Baduy memiliki anekaragam atau diversifikasi pangan karbohidrat dan non karbohidrat dari anekaragam produsi tanaman, namun untuk pemenuhan kebutuhan kecukupan pangan berupa protein hewani, cenderung kurang terpenuhi. Mengingat berbagai pasokan pangan sumber protein hewani, seperti ikan asin peda, ikan asin Belitung, ikan asin teri, pindang, ikan mas, tahu, tempe, telur dan lainnya lebih mengandalkan hasil membeli dari warung-warung atau pasar (bandingkan Khomsan dan Wigna 2009). Oleh karena itu, bagi keluarga Baduy yang tidak memiliki kecukupan uang tunai, bisa mengalami kendala untuk mendapat kecukupan pasokan sumber protein hewani.

Masyarakat Baduy selain memiliki kearifan ekologi mampu menyimpan padi-padi 


\section{JURNAL BIODJATI}

http://journal.uinsgd.ac.id/index.php/biodjati

gabah dalam kurun waktu lama di leuit, mereka juga dapat mengelola benih-benih padi lokal secara mandiri dengan dilandasi kuat oleh pengetahuan ekologi lokal dan dibalut kuat oleh kepercayaan atau kosmos. Padi bakal benih padi diharuskan disimpan secara terpisah dari padi-padi lainnya. Padi-padi bakal benih tersebut diperoleh dari hasil panen padi sebelumnya. Caranya, sewaktu panen padi,dari setiap varietas (huasan) nya dipilih butir-butir gabah yang dianggap unggul, seperti berisi dan seragam. Kemudian, ikatanikatan padi gabah bakal benih tersebutdisimpan secara khusus, misalnya disimpan di rumah-rumah ataupun dimasukan pada peti-peti kayu, khususnya di masyarakat Baduy Luar.

Berdasarkan tradisi masyarakat Baduy, setiap keluarga Baduy yang memiliki ladang cukup luas, minimal 0,5 ha, diwajibkan pada petak ladangnya ditanami 3 varietas padi sakral, pare koneng, pare siang, dan pare ketan langgasari,serta ditambah pula dengan beberapa varietas padi lainnya yang dianggap non-sakral, seperti pare seungkeu, pare pendok, pare tunggul dan lainnya. Ketiga varietas padi sakral tersebut secara adat diharuskan ditanam di setiap petak ladang secara terpisah, tidak boleh bersinggungan. Pare koneng diharuskan ditanam di bagian tengah petak ladang, pare siang di bagian timur dan pare ketan langgasari di bagian barat. Sementara itu, untuk menjaga agar 3 varietas padi sakral tersebut tidak bersinggungan satu sama lainnya, maka lokasi di antara ketiganya biasanya disisipkan beberapa varietas padi lainnya, berupa padi non-sakral. Pada saat panen padi ladang, ketiga varietas padi sakral yang bakal dijadikan bahan benih baru, pada setiap varietasnya diambil tidak dari bagian pinggirnya, tapi bagian tengahnya. Tata cara pengambilan tangkai-tangkai padi pada bagian tengah petak tersebut dimaksidkan agar butir-butir gabah padi benar-benar merupakan varietasnya murni, yang tidak bersinggungan dengan varitetas lainnya. Kebiasaan masyarakat Baduy (pandangan emik) tersebut cukup sejalan dengan pengetahuan ilmiah Barat (pandangan etik). Pasalnya, secara ekologi (pandangan etik), tanaman padi (Oryza sativa $\mathrm{L}$ ) dapat bersilangan antara varietasnya, sehingga dengan pemisahan tempat penanamannya di petak-petak ladang,dapat menghindari dari penyerbukan silang antar varietasnya guna menjaga kemurnian varietas padi tersebut (Richards 1994; Cotton 1996; Setyawati, 1999 ; Pfeiffer, 2006). Selain itu, dengan adanya tradisi masyarakat Baduy diwajibkan penanaman varietas padi secara dipisah-pisahkan pada petak ladang, juga mendorong penduduk Baduy untuk menanam keanekaan varietas padi yang tinggi. Pasalnya, pada suatu petak lahan ladang keluarga, minimal harus ditanam 3 varietas padi sakral, dan beberapa varietas padi lainnya non-sakral, sebagai pemisah di antara varietas padi sakral tersebut. Oleh karena itu, tidaklah heran bahwa di masyarakat Baduy Dalam dan masyarakat Baduy Luar tercatat secara total 89 varietas (landraces) padi ladang lokal (Iskandar dan Ellen 1999).Padahal, kini keanekaan varietas padi sawah sangat rendah, karena sebagian dari anekaragam varietas padi lokal sawah telah terdesak oleh anekaragam varietas padi unggul baru, seperti IR64, PB5 dan lainnya yang diperkenalkan secara masif lewat program Revolusi Hijau (Fox, 1991). Anekaragam padi lokal diklasifikasikan masyarakat Baduy (folk classification) berdasarkan bentuk morfologi butir gabah; berbulu dan tidak berbulunya butir gabah; bentuk dan warna bulu; umur tanam; warna beras; dan cita rasa kuliner nasi, seperti pulen dan tidak pulennya nasi yang ditanak (Iskandar dan Ellen 1999). 


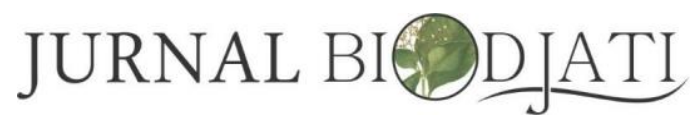

http://journal.uinsgd.ac.id/index.php/biodjati

Berdasarkan hasil studi ini dapat disimpulkan bahwa masyarakat Baduy memiliki kearifan ekologi dalam mengkonservasi anekaragam benih padi lokal secara in-situ, dan juga mampu menyimpan padi di leuit secara berkelanjutan untuk jangka panjang. Maka, seyogianya kearifan ekologi Orang Baduy tersebut dapat dipadukan dengan pengetahuan ilmiah Barat, guna dimanfaatkan dalam progam pembangunan keamanan dan ketahanan pangan secara berkelanjutan berbasis pemberdayaan masyarat di Indonesia.

\section{DAFTAR PUSTAKA}

Adimihardja, K. (1991). The Traditional Agricultural Rituals and Practices of the Kasepuhan Community of West Java. Indo Pacific Prehistory Assn.Bulletin 10 : 226-234.

Al Ansori, A. M., Ratnasari, S.M., Nurhanifah, Alfajri, R., \& Aji, D. N. (2015). Teknologi Leuit Baduy: Lumbung Padi Tahan Hama dan Busuk. Program Kreativitas Mahasiswa, Unpad.

Albuquerque, U. P., da Cunha, L. V. F. C., RFP de Lucena, R. E. P., \& Alves, R.R.N., (eds) (2014). New York: Methods and Techniques in Ethnobiology. Springer Science-Business Media.

Arisetyawan, A., Suryadi, D., Herman, T., \& Rahmat, C. (2014). Study Ethnomathematics : A Lesson From Baduy Culture. International Journal of Education and Research 2 (10): 681-688.

Berkes, F. 2008. New York: Sacred Ecology. Routledge.

Carlson, T. J. S., \& Maffi, L. (2004). Introduction: Ethnobotany and Conservation of Biocultural Diversity. In Carslson, T.J.S, and Maffi, L. (eds), Ethnobotany and Conservation of Biocultural Diversity. New York: The
New York Botanical Garden, New York, pp.1-6.

Cotton, C. M. (1996). Ethnobotany: Principles and Application. England: John Willey and Sons Ltd.

Ellen, R., \& Harris, H. (2000). Introduction. In Ellen, R. Parkes, P and Bicker, A. (eds), Indigenous Environmental Knowledge and Transformations. Amsterdam: Harwood Academic, pp.1-33.

Fox, J. J. (1991). Managing the Ecology of Rice Production in Indonesia. Dalam Hardjono, J. (ed), Indonesia: Resources, Ecology, and Environment. Singapore: Oxford University Press.

Fox, J. (2016). Serangga yang Berkembang biak secara Cepat Mengancam Produksi Padi di Jawa. Dalam Winarto, Y.T. (ed), Krisis Pangan dan "Sesat Pikir" : Mengapa Masih Berlanjut. Jakarta : Yayasan Pustaka Obor Indonesia, pp. 4144.

Ichwandi, I., \& Shinohara, T. (2007). Indigenous Parctices for use of and managing tropical natural resources: A Case study on Baduy Community in Banten, Indonesia. Tropics 16 (2): 87-102.

IRRI (The International Rice Research Institute). (2004). Training-ManualGrain-Storage. The International Rice Research Institute, USA.

Iskandar, J., \& Ellen, R. (1999). In Situ Conservation of Rice Landraces Among the Baduy of West Java. Journal of Ethnobiology 19 (1) : 97-125.

Iskandar, J., \& Iskandar, B. S. (2011). Agroekosistem Orang Sunda. Bandung: Buku Kiblat Utama Press. Iskandar, J., and Iskandar, B.S. 2017. Various Plants of Traditional Rituals: Ethnobotanical Research Among the Baduy Community. Biosaintifika 9 (1) : 114-125. 


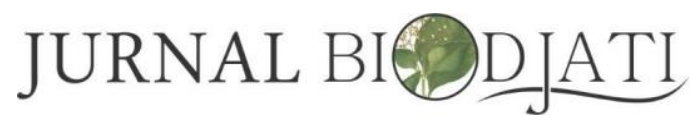

http://journal.uinsgd.ac.id/index.php/biodjati

Jamaludin, (2012). Makna Simbolik Huma (Ladang) di Masyarakat Baduy. Jurnal Ilmu Humaniora 11 (1) : 1-91.

Jamaludin, Permadi, G. M. I., \& Kharisma, M. C. (2013). Tinjauan Arsitektur Internasional Desa Kanekes. Jurnal Rekajiva, Jurnal Online Institut Teknologi Nasional. Jurusan Interior Desain Interior, Itenas No. x. Vol xx: 1-15.

Khomsan, A., \& Wigna, W. (2009). SosioBudaya Pangan Baduy. Jurnal Gizi dan Pangan 4 (2) : 63-71.

Marfori, M. C., Kajima, S. I., Fukusaki, E., \& Kobayashi, A. (2015). Lansioside D, a new triterpenoid glycoside antibiotic from the fruit of Lansium domesticum Correa. Journal of Pharmacognocy and Phytochemstry 3 (5) : 140-143.

Martin, G. J. (1995). Ethnobotany : a Methods Manual. London: Chapman and Hall.

Newing, H., Eagle, C. M., Puri, R. K., \& Watson, C.W. (2011). Conducting Research in Conservation: Social Science methods and Practice. London and New York : Routledge.

Pfeiffer, J. M., Dun, S., Mulawarman, B., \& Rice, K.J. (2006). Biocultural Diversity in Traditional Rice Base Agroecosystems: Indigenous Research and Conservation maco (Oryza sativa L.) Upland Rice Landraces of Eastern Indonesia. Envir Dev Sutain. Springer Since + Business Media M.V. DOI 10.1007/s 10668-0069047-2.

Prabowo, R. (2010). Kebijakan Pemerintah Dalam Mewujudkan Ketahanan Pangan di Indonesia. Mediagro6 (2):62-73.

Reijintjes, C., Haverkort, B., \& Waters-Bayer, A. (1992). Farming for the Future: An Introduction to Low-External-Input and Sustainable Agiculture. London and Basingstoke : The Macmillan PressLtd.
Richards, P. (1994). Local knowledge formation and validation: the case of rice production in central Sierra Leone. In Scoones, I., Thomson, J. (eds), Beyond Farmer First: Rural People's Knowledge, Agriculture Research and Extension Practice. London: Intermediate Technology Publications, pp.165-170.

Setyawati, I. (1999). Pengetahuan tentang varietas-varietas padi dan pemanfaatannya di kalangan Orang Kenyah Leppo'ke di Apau Ping. Dalam Eighenter, C. dan Sellato, B. (eds), Kebudayaan dan Pelestarian Alam: Penelitian Interdisipliner di Pedalaman Kalimantan. WWF Indonesia, Jakarta, pp. 97-113.

Sillitoe, P. (2002). Globalizing indigenous knowledge. In Sillitoe, P., Bicker, A., and Pottier, J. (eds), Participating in Development: Apporoaches to Indigenous Knowledge. London and New York: Routledge, pp. 108-138.

Suparmini, Setyawati, S., \& Sumunar, D. R. S. 2013. Pelestarian Lingkungan Masyarakat Baduy Berbasis Kearifan Lokal. Jurnal Penelitian Humaniora 18 (1): 8-22.

Toledo, V. M. (2000). Ethnoecology: A conceptual framework for the study of indigenous knowledge on nature. Plenary lecture, Seventh International Congress of Ethnobiology, Athens, Ga, 22-27 October 2000.

Wessing, R., \& Barenregt, B. (2005). Tending the Spirit's Shrin: Kanekes and Pajajaran in West Java. Moussons 8:3-26.

Winarto, Y. T. (2016). Mengatasi "Ancaman Krisis Pangan" dan Menanggulangi "Sesat Pikir": Suatu Pengantar. Dalam Winarto, Y. T. (ed), Krisis Pangan dan "Sesat Pikir": Mengapa Masih Berlanjut?. Jakarta : Yayasan Obor Indonesia Jakarta. pp:1-20 